\title{
Effects of myrrh on the strength of suture materials: an in vitro study
}

\author{
Mohammed A. ALSHEHRI ${ }^{1}$, Jagan Kumar BASKARADOSS² ${ }^{2}$ Amrita GEEVARGHESE ${ }^{3}$, \\ Ravikumar RAMAKRISHNAIAH ${ }^{4}$ and Dimitris N. TATAKIS ${ }^{5}$ \\ ${ }^{1}$ College of Medicine and University Hospitals, King Saud University, Riyadh, Saudi Arabia \\ ${ }^{2}$ Department of Dental Public Health, School of Dental Medicine, Case Western Reserve University, Cleveland, Ohio, USA \\ ${ }^{3}$ Department of Dental Public Health, College of Dentistry, King Saud Bin Abdulaziz University for Health Sciences, King Abdulaziz Medical City, \\ Riyadh, Saudi Arabia \\ ${ }^{4}$ Department of Dental Health, College of Applied Medical Sciences, King Saud University, Riyadh, Saudi Arabia \\ ${ }^{5}$ Division of Periodontology, College of Dentistry, The Ohio State University, Columbus, Ohio, USA \\ Corresponding author, Mohammed A.ALSHEHRI; E-mail:dr_mzs@hotmail.com
}

The present in vitro study sought to determine the effects of myrrh-containing solutions on common suture materials used in periodontal surgery. Three commonly used suture materials (silk, polyglactin 910, polytetrafluoroethylene) were immersed in four thermostatically controlled experimental media to simulate daily oral rinsing activity, namely —artificial saliva, normal saline solution with $0.2 \%$ Commiphora myrrh, full-concentration (100\%) Commiphora myrrh oil, and a myrrh-containing commercial mouthwash. Tensile strength was measured at the end of each day using an Instron tensile testing machine. Silk sutures were susceptible to tensile strength loss when exposed to $0.2 \%$ myrrh solution once daily for 5 days. Myrrh-containing commercial mouthwash had no effect on tensile strength, but all three suture materials lost tensile strength when exposed to $100 \%$ myrrh oil. For patients that routinely use myrrh mouthwashes postoperatively, findings of this study suggested that silk sutures might not be the optimal material choice.

Keywords: Myrrh, Suture materials, Tensile strength, Wound healing

\section{INTRODUCTION}

A two-pronged approach of using the appropriate suturing technique and suture material plays a critical role in avoiding wound failures, and is key to proper postoperative tissue positioning and adaptation ${ }^{1-5}$. Sutures may degrade and lose their desirable material properties due to extended exposure in hostile environments, such as the stomach which is highly acidic $^{6}$. The oral cavity is an environment with significant variations in both temperature and $\mathrm{pH}$ conditions. Such fluctuations are caused by the ingestion of various foods and drinks, as well as the use of oral healthcare products such as toothpastes and mouthwashes. In the oral cavity, different suture materials not only elicit different oral soft tissue responses ${ }^{7-12)}$, they also exhibit different behaviors ${ }^{8,11,13,14)}$. In vitro studies have examined the material properties of suture materials used in the oral cavity, and a commonly investigated property is their tensile strength ${ }^{6,15,16)}$.

Among the numerous available absorbable and non-absorbable suture materials, silk, polyglactin 910 (PLG), and polytetrafluoroethylene (PTFE) are commonly used in oral and periodontal procedures. Silk is the most commonly used natural suture material, due to its superior handling characteristics ${ }^{14)}$. PLG is also a commonly used synthetic suture material because it is absorbable ${ }^{17)}$. It is made from $90 \%$ glycolide

Color figures can be viewed in the online issue, which is available at J-STAGE.

Received Nov 6, 2013: Accepted Sep 25, 2014

doi:10.4012/dmj.2013-317 JOI JST.JSTAGE/dmj/2013-317 and $10 \%$ L-lactide, and coated with calcium stearate and a copolymer of lactic acid and glycolic acid. PTFE suture is a polymer of carbon chain with fluoride atoms surrounding it, and it has been largely used in orthopedic and vascular surgeries ${ }^{18}$. PTFE is a biologically and chemically inert, biocompatible, and autoclavable synthetic suture material ${ }^{19,20}$. It does not adhere to tissue and is therefore easily removed.

More than $60 \%$ of the global population uses herbal medicines as alternative remedies ${ }^{21}$. Some healthcare professionals may even prefer to use herbal medicines rather than synthetic drugs ${ }^{22)}$. Myrrh is an aromatic resinous exudate obtained mainly from trees of certain Commiphora species of the Burseraceae family ${ }^{23}$. Evidence suggests that myrrh can be used to treat ulcers, fasciolopsis, respiratory catarrh, furunculosis, and diabetes ${ }^{24-29}$. A tincture of myrrh in alcohol is typically used as an oral astringent and mouthwash, especially for treating painful throat infections ${ }^{30)}$. Traditionally, myrrh was used to treat sore throats and cough, burns, external wounds, and even joint inflammation and tendonitis $\mathrm{s}^{31}$. Minimum inhibitory concentrations of myrrh have been reported to inhibit common bacterial and fungal pathogens, such as Escherichia coli, Staphylococcus aureus, Candida albicans, and Pseudomonas aeruginosa ${ }^{32)}$. Studies have also explored the anticancer and pain-relieving potentials of myrrh resin $^{33,34)}$.

Evidence suggests that toothpastes and mouthwashes which contain myrrh are effective in 
preventing and treating gingival inflammation ${ }^{35,36)}$. In a recent animal study by $\mathrm{Al}-\mathrm{Mobeeriek}^{30)}$, a dilute myrrh suspension was found to promote the healing and repair of damaged oral tissues. The same study reported possible harmful effects of myrrh when used in excess or over long periods due to either overdosing or inherent adverse reactions to myrrh. Relatively few studies have addressed the potential adverse effects and toxicity of myrrh $^{37-39)}$.

On the one hand, sutures are routinely used in periodontal and oral surgeries. On the other hand, myrrh-containing mouthwashes are routinely used during the postoperative period. However, the potential effects of myrrh in myrrh-containing mouthwashes on suture materials have not been investigated. Therefore, the purpose of the present in vitro study was to determine the effects of different myrrh solutions on the tensile strength of the three aforementioned suture materials commonly used in periodontal surgical procedures.

\section{MATERIALS AND METHODS}

\section{Study design}

Three different suture materials were exposed to different media (1 control, 3 test) to simulate possible short-term intraoral exposure to different oral rinses. In summary, suture materials were immersed in artificial saliva and after 24-120 h, test samples were exposed for $1 \mathrm{~min}$ to the test media and then measured for tensile strength. The 1-min exposure to the respective test media followed by tensile strength measurement was repeated every $24 \mathrm{~h}$ up to $120 \mathrm{~h}$.

\section{Study materials}

Tested suture materials were obtained from commercially available, unexpired, sterilized packets. They were namely -4-0 silk (Mersilk ${ }^{\mathrm{TM}}$, Ethicon Inc., Somerville, NJ, USA), 5-0 PLG (Vicryl ${ }^{\mathrm{TM}}$, Ethicon), and CV-4 PTFE (Gore-Tex ${ }^{\circledR}$ Suture, WL Gore \& Associates, Inc., Flagstaff, AZ, USA).

Four thermostatically controlled experimental media were used for suture exposure: (1) Control group (CG) —artificial saliva; (2) Test group-1 (TG-1) — Normal saline solution with $0.2 \%$ Commiphora myrrh (finely powdered myrrh obtained from a traditional market and diluted in $0.9 \%$ sodium chloride) ${ }^{30)}$; (3) Test group-2 (TG-2) -Full-concentration (100\%) Commiphora myrrh oil; and (4) Test group-3 (TG-3) - Parodontax ${ }^{\circledR}$ mouthwash (which contained caraway oil, chamomile, clove oil, echinacea purpurea, menthol, mint oil, myrrh, peppermint oil, sage oil; GlaxoSmithKline Consumer Healthcare, Bühl, Germany).

Artificial saliva was prepared by mixing $100 \mathrm{~mL}$ each of $25 \mathrm{mM} \mathrm{K}_{2} \mathrm{HPO}_{4}, 24 \mathrm{mM} \mathrm{Na}_{2} \mathrm{HPO}_{4}, 1,570 \mathrm{mM} \mathrm{KHCO}_{3}$, $100 \mathrm{mMNaCl}$, and $1.5 \mathrm{mM} \mathrm{MgCl}_{2}$, followed by adding 6 $\mathrm{mL}$ of $25 \mathrm{mM}$ citric acid and $100 \mathrm{~mL}$ of $15 \mathrm{mM} \mathrm{CaCl}_{2}$. The $\mathrm{pH}$ was adjusted to 6.7 with $5 \mathrm{~N} \mathrm{NaOH}$ or concentrated $(12 \mathrm{~N}) \mathrm{HCl}$. The solution was sterilized by autoclaving. After cooling to ambient temperature, human salivary $\alpha$-amylase (Sigma-Aldrich Canada Ltd., Ontario,
Canada) and chicken egg white lysozyme (SigmaAldrich) were added at 1 and $0.1 \mathrm{~g} / \mathrm{L}$ respectively ${ }^{40,41}$. All media were thermostatically controlled at $37 \pm 1^{\circ} \mathrm{C}$ during the immersion/exposure periods.

\section{Testing procedures}

For each of the three suture materials, 100 samples were obtained thereof, resulting in a total of 300 suture samples, each measuring approximately $20 \mathrm{~cm}$ in length. All samples were immersed in artificial saliva. After 24 h, 60 samples ( $n=20$ per suture material) were removed and either immediately tested for tensile strength (CG; $n=5$ per suture material) or immersed for $60 \mathrm{~s}$ in one of the three test media (TG-1, TG-2, and TG-3; $n=5$ samples per suture per test group). After 60 -s immersion, samples were immediately tested for tensile strength.

The remaining samples $(n=240)$ were either left in artificial saliva (CG; $n=20$ samples per suture material) or immersed for $60 \mathrm{~s}$ in the test media $(n=80$ per test media; 20 samples per suture material). After washing, the latter were returned to the artificial saliva bath for another $24 \mathrm{~h}$. This process was repeated at 48, 72, 96, and $120 \mathrm{~h}$, with 60 samples ( $n=20$ per suture material; 5 samples per media group) tested for tensile strength at each time point.

An Instron material testing machine (8500/8800 system, Instron Ltd., High Wycombe, UK) connected to a computer was used to test the tensile strength of the samples. Tensile strength was determined by a single pull to suture failure, under a 50-N capacity load cell at a constant crosshead speed of $50 \mathrm{~mm} / \mathrm{min}$. Immersed/ exposed suture samples were knotted with four simple square knots to each of the two fixed hooks on the Instron machine's fixation device; preliminary testing indicated that this experimental setup did not lead to suture failure at the hooks or knots. Maximum force in Newtons applied to the suture prior to failure was recorded as the breaking strength for that suture sample.

\section{Statistical analysis}

Data had normal distribution when tested with ShapiroWilk test for normality. Analysis of variance (ANOVA) was used to compare the mean tensile strengths of the suture materials. A $p$-value of $<0.05$ was considered statistically significant. Levels of significance were adjusted using the Bonferroni formula for multiple comparisons. All statistical analyses were performed using SPSS 17.0 (Statistical Package for the Social Sciences for Windows ${ }^{\circledR}$, SPSS Inc., Chicago, IL, USA).

\section{RESULTS}

Table 1 lists the tensile strength results of the different suture materials. Tensile strengths of all the tested suture materials were not affected by immersion in artificial saliva (CG; Fig. 1). In TG-1, significant differences were observed for silk between Day 1 and Day 5 results (Fig. 2). In TG-2, Day 1 result of silk was significantly different from Days 4 and 5; for PLG and PTFE, their Day 1 results were significantly different 
from Days 3-5 (Fig. 3). As with CG, immersion in TG-3 did not affect the tensile strength of any of the tested suture materials at any time point (Fig. 4).
Among the test media, TG-2 (100\% myrrh oil) led to the greatest reduction in tensile strength. TG-2 negatively affected the tensile strength of all three

Table 1 Maximum tensile strength (Newtons) at failure, over time (mean \pm SD)

\begin{tabular}{|c|c|c|c|c|c|c|c|c|c|c|c|c|}
\hline & \multicolumn{3}{|c|}{$\begin{array}{l}\text { Artificial Saliva } \\
\text { (CG) }\end{array}$} & \multicolumn{3}{|c|}{$\begin{array}{l}0.2 \% \text { myrrh } \\
\quad(\mathrm{TG}-1)\end{array}$} & \multicolumn{3}{|c|}{$\begin{array}{c}100 \% \text { myrrh } \\
\text { (TG-2) }\end{array}$} & \multicolumn{3}{|c|}{$\begin{array}{c}\text { Commercial Rinse } \\
\text { (TG-3) }\end{array}$} \\
\hline & Silk & PLG & PTFE & Silk & PLG & PTFE & Silk & PLG & PTFE & Silk & PLG & PTFE \\
\hline Day 1 & $9.4 \pm 0.6$ & $12.8 \pm 0.7$ & $19.9 \pm 0.3$ & $9.3 \pm 0.1$ & $12.6 \pm 0.4$ & $19.8 \pm 0.5$ & $9.4 \pm 0.4$ & $12.9 \pm 0.8$ & $20.1 \pm 0.6$ & $9.5 \pm 0.2$ & $12.4 \pm 0.3$ & $19.9 \pm 0.1$ \\
\hline Day 2 & $9.3 \pm 0.1$ & $12.7 \pm 0.6$ & $19.8 \pm 0.1$ & $9.1 \pm 0.3$ & $12.6 \pm 0.3$ & $20.4 \pm 0.9$ & $9.1 \pm 0.3$ & $12.7 \pm 0.8$ & $19.7 \pm 0.2$ & $9.3 \pm 0.5$ & $12.4 \pm 0.5$ & $19.9 \pm 0.7$ \\
\hline Day 3 & $9.4 \pm 0.2$ & $12.6 \pm 0.8$ & $19.8 \pm 0.4$ & $9.2 \pm 0.8$ & $12.4 \pm 0.2$ & $20.1 \pm 0.6$ & $8.8 \pm 0.2^{*}$ & $12.3 \pm 0.7^{\#}$ & $18.2 \pm 0.6^{* \#}$ & $9.3 \pm 0.2$ & $12.3 \pm 0.1$ & $19.8 \pm 0.9$ \\
\hline Day 4 & $9.2 \pm 0.1$ & $12.6 \pm 0.4$ & $19.7 \pm 0.6$ & $8.9 \pm 0.5$ & $12.2 \pm 0.3$ & $20.0 \pm 0.4$ & $8.2 \pm 0.1^{\text {*\# }}$ & $11.2 \pm 0.7^{\text {*\# }}$ & $17.3 \pm 0.9^{* \#}$ & $9.1 \pm 0.8$ & $12.4 \pm 0.1$ & $19.8 \pm 0.5$ \\
\hline Day 5 & $9.0 \pm 0.5$ & $12.5 \pm 0.5$ & $19.6 \pm 0.8$ & $8.6 \pm 0.2^{* \#}$ & $12.2 \pm 0.1$ & $19.3 \pm 0.2$ & $6.8 \pm 0.6^{* \#}$ & $10.6 \pm 0.2^{* \#}$ & $16.4 \pm 0.1^{\text {*\# }}$ & $9.0 \pm 0.4$ & $12.3 \pm 0.3$ & $19.8 \pm 0.5$ \\
\hline
\end{tabular}

* Significantly different compared to corresponding control $(p<0.05)$

\# Significantly different compared to corresponding Day 1 value $(p<0.05)$

$n=5$ for all reported values

CG: Control group; PLG: Polyglactin 910; PTFE: polytetrafluoroethylene; TG: test group

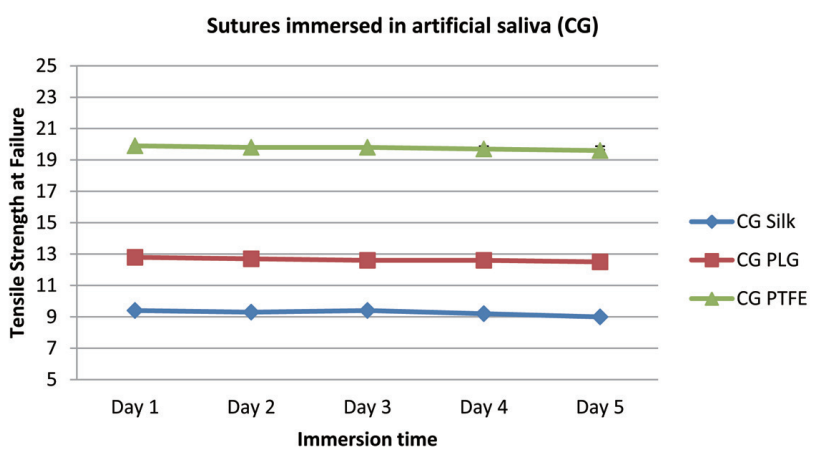

Fig. 1 Line graph showing the changes in tensile strength over time for tested suture materials immersed in artificial saliva (CG).

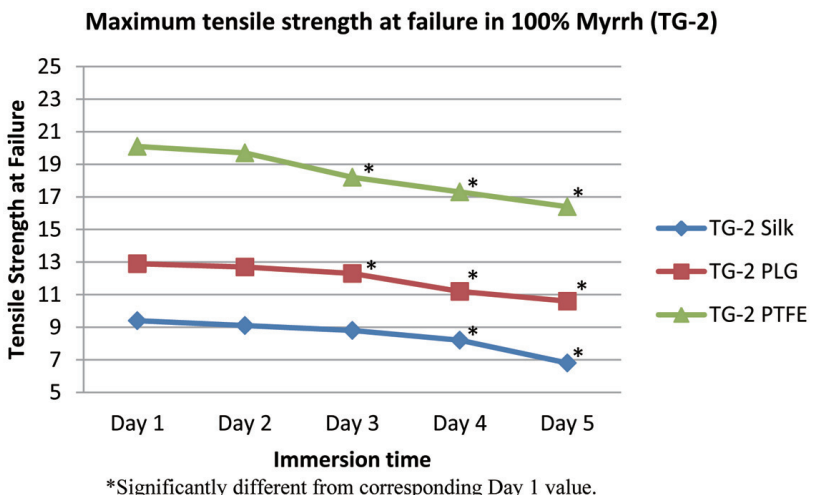

Fig. 3 Line graph showing the changes in tensile strength over time for tested suture materials immersed in $100 \%$ myrrh (TG-2).

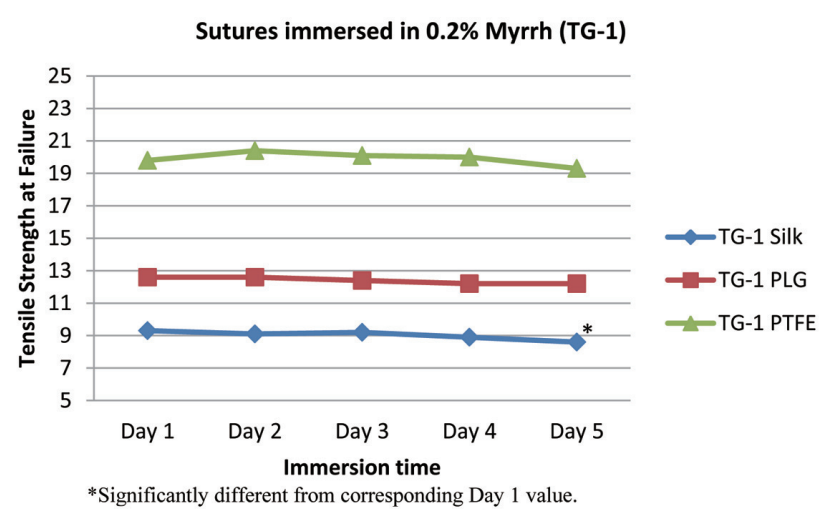

Fig. 2 Line graph showing the changes in tensile strength over time for tested suture materials immersed in $0.2 \%$ myrrh (TG-1).

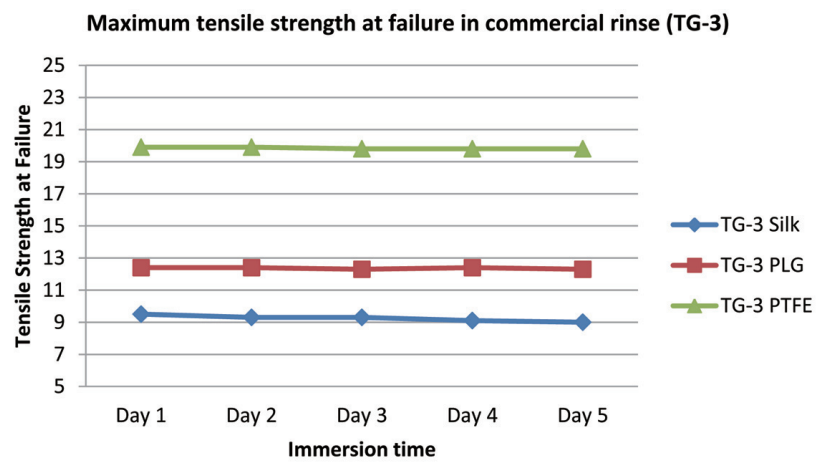

Fig. 4 Line graph showing the changes in tensile strength over time for tested suture materials immersed in a commercial mouthwash which contained myrrh (TG-3). 
Table 2 Maximum tensile strain $(\mathrm{mm} / \mathrm{mm})$ at failure at Day 1 and Day 5 (mean $\pm \mathrm{SD})$

\begin{tabular}{|c|c|c|c|c|c|c|c|c|c|c|c|c|}
\hline & \multicolumn{3}{|c|}{$\begin{array}{l}\text { Artificial Saliva } \\
\text { (CG) }\end{array}$} & \multicolumn{3}{|c|}{$\begin{array}{c}0.2 \% \text { myrrh } \\
(\mathrm{TG}-1)\end{array}$} & \multicolumn{3}{|c|}{$\begin{array}{c}100 \% \text { myrrh } \\
\text { (TG-2) }\end{array}$} & \multicolumn{3}{|c|}{$\begin{array}{l}\text { Commercial Rinse } \\
\text { (TG-3) }\end{array}$} \\
\hline & Silk & PLG & PTFE & Silk & PLG & PTFE & Silk & PLG & PTFE & Silk & PLG & PTFE \\
\hline Day 1 & $0.57 \pm 0.2$ & $3.12 \pm 0.2$ & $0.83 \pm 0.2$ & $0.78 \pm 0.1$ & $1.54 \pm 0.1$ & $1.13 \pm 0.1$ & $0.71 \pm 0.2$ & $0.96 \pm 0.3$ & $1.07 \pm 0.2$ & $0.58 \pm 0.1$ & $2.15 \pm 0.1$ & $0.77 \pm 0.3$ \\
\hline Day 5 & $0.46 \pm 0.1$ & $2.05 \pm 0.2$ & $0.72 \pm 0.1$ & $0.40 \pm 0.2$ & $2.03 \pm 0.2$ & $0.68 \pm 0.1$ & $0.41 \pm 0.1$ & $1.47 \pm 0.1$ & $1.99 \pm 0.1^{*}$ & $0.69 \pm 0.1$ & $2.95 \pm 0.3$ & $1.11 \pm 0.2$ \\
\hline
\end{tabular}

* Significantly different compared to corresponding Day 1 value $(p<0.05)$

$n=5$ for all reported values

CG: Control group; PLG: Polyglactin 910; PTFE: polytetrafluoroethylene; TG: test group

tested suture materials. Silk and PTFE showed significant reduction in tensile strength by Day 3, while that of PLG was significantly reduced by Day 4 .

Of the three suture materials, silk exhibited the greatest loss in tensile strength from myrrh exposure. At the end of the study (Day 5), the tensile strength of silk suture was reduced by almost 30\% in TG-2, compared to less than $20 \%$ reduction in tensile strength for the other two tested suture materials. Silk was the only suture material negatively affected by TG-1. TG-3 (commercial mouthwash which contained myrrh) had no significant effect on any of the suture materials. Table 2 shows the maximum tensile strain values (at failure) on Day 1 and Day 5. Tensile strain values of PTFE in TG-2 were significantly different between Day 1 and Day 5 .

\section{DISCUSSION}

The present in vitro study aimed to determine the effects of different concentrations of myrrh solutions on the tensile strength of three commonly used suture materials. Results showed that: (a) silk sutures were susceptible to tensile strength loss when exposed to $0.2 \%$ myrrh solution once daily for 5 days; (b) all tested suture materials lost tensile strength when exposed to $100 \%$ myrrh oil; and (c) myrrh-containing commercial mouthwash had no effect on suture tensile strength. To the best of our knowledge, this is the first study to investigate the effects of myrrh-containing solutions on the strength of suture materials.

Myrrh is composed of gum (57-61\%), resin (25-40\%), essential oil (7-17\%), and impurities (3-4\%) ${ }^{42-44)}$. Myrrh is widely used in Saudi Arabia as a home remedy ${ }^{45,46}$ because of its antiseptic ${ }^{47)}$ and astringent properties ${ }^{48)}$. Previous reports have indicated that myrrh can be used to treat several inflammatory conditions - as an antipyretic, an antiseptic, a stimulant, a mouthwash, as well as for treating spleen, liver, stomach, breast, head, nose and eye tumors ${ }^{49,50)}$.

The tensile strength of suture materials is an important property that indicates the ability of the material to withstand stress during knotting ${ }^{51)}$. The three most commonly used intraoral suture materials, namely -silk, polyglactin 910, and polytetrafluoroethylene- were investigated in this study. Three types of experimental media containing varying concentrations of myrrh were used. TG-1 contained $0.2 \%$ myrrh, which is the most common practice of myrrh use in the Saudi population ${ }^{30)}$. TG-2 contained $100 \%$ myrrh oil, a supraphysiologic test solution, which was used to determine whether myrrh would cause suture material deterioration at higher concentrations. TG-3 was an internationally available commercial mouthwash, Parodontax ${ }^{\circledR}$, which contained myrrh leaf extract. The choice of experimental media allowed comparisons between various myrrh-containing solutions, ranging from local mouthwash (TG-1) to internationally available preparation (TG-3). Suture materials were exposed to the various test media for 1 min per day, which is considered as the average time mouthwashes are used intraorally ${ }^{52,53)}$.

Majority of the existing suture material literature is based on studies that were performed on skin and subcutaneous tissues ${ }^{51,54-56)}$. More extreme environments, such as that posed by pancreatic juice ${ }^{57)}$, were found to have significant effects on suture strength and integrity. Therefore, the strength of suture materials might be influenced by external factors presented by the physiological environment of the sutures. This is especially true with the sutures placed in the oral cavity because of the type of tissues involved, the constant presence of saliva, high tissue vascularization, and significant variations in local conditions (e.g., temperature, acidity, osmolarity) arising from the consumption of foods and drinks and the use of toothpastes and mouthwashes.

In a study by McCaul and coworkers ${ }^{58)}$ which investigated the effect of chlorhexidine mouthwash on the absorption time on polyglactin 910 (PLG), it was reported that the mouthwash had no significant effect on the survival of suture material. PLG degradation due to tensile strength loss in vivo is secondary to proteolytic enzymatic degradation. PLG, when exposed to saliva, showed more rapid tensile strength loss, especially after 7 days $^{59)}$. A recent in vitro study reported that 5-0 PLG degraded more rapidly than $4-0 \mathrm{PLG}^{60)}$. PTFE was reported to have good resistance against infection and the action of tissue enzymes ${ }^{61)}$.

In the present study, degradation rates of PLG and PTFE did not appear to be adversely affected by $0.2 \%$ 
myrrh or Parodontax. However, the strength of silk was significantly reduced when exposed to even the lowest myrrh concentration. Although silk is classified as a non-resorbable material, it is known to be subject to proteolytic degradation but over a longer time ${ }^{62)}$. It was also reported that the tensile strength of silk decreased upon exposure to saliva ${ }^{14)}$. In the present study, all three suture materials exhibited significant strength reductions when exposed to $100 \%$ myrrh. The effect was most noticeable after Day 3. Although this concentration is not used intraorally, the result helped to confirm the effect of myrrh on suture materials.

The exact mechanism by which myrrh causes reduction in the strength of suture materials is unclear. Molecular analysis of the suture materials could probably provide more information on their interaction with myrrh. However, this is beyond the scope of the present investigation.

\section{CONCLUSION}

The tensile strength of silk sutures was significantly reduced by exposure to myrrh. For patients that routinely use myrrh-containing mouthwashes postoperatively, the findings of this study suggest that silk sutures might not be the optimal material choice. Appropriately designed clinical studies are needed to confirm the in vitro findings of this study.

\section{ACKNOWLEDGMENTS}

The authors would like to express their appreciation to the Research Center, College of Applied Medical Sciences and Deanship of Scientific Research at King Saud University, for funding this research.

On potential conflicts of interest, the authors declare no conflicts of interest relevant to this article.

\section{REFERENCES}

1) Moy RL, Waldman B, Hein DW. A review of sutures and suturing techniques. J Dermatol Surg Oncol 1992; 18: 785795.

2) Carlson MA. Acute wound failure. Surg Clin North Am 1997; 77: 607-636

3) Ivanoff CJ, Widmark G. Nonresorbable versus resorbable sutures in oral implant surgery: a prospective clinical study. Clin Implant Dent Relat Res 2001; 3: 57-60.

4) Poole GV Jr, Meredith JW, Kon ND, Martin MB, Kawamoto EH, Myers RT. Suture technique and wound-bursting strength. Am Surg 1984; 50: 569-572.

5) Silverstein LH, Kurtzman GM, Kurtzman D. Suturing for optimal soft tissue management. Gen Dent 2007; 55: 95-100.

6) Chu CC, Moncrief G. An in vitro evaluation of the stability of mechanical properties of surgical suture materials in various pH conditions. Ann Surg 1983; 198: 223-228.

7) Wallace WR, Maxwell GR, Cavalaris CJ. Comparison of polyglycolic acid suture to black silk, chromic, and plain catgut in human oral tissues. J Oral Surg 1970; 28: 739-746.

8) Racey GL, Wallace WR, Cavalaris CJ, Marguard JV. Comparison of a polyglycolic-polylactic acid suture to black silk and plain catgut in human oral tissues. J Oral Surg 1978; 36: 766-770.
9) Okamoto T, Gabrielli MF, Gabrielli MA. Influence of different types of non-resorbable suture material on the healing of extraction wounds - a histological study in rats. J Nihon Univ Sch Dent 1990; 32: 104-115.

10) Abi Rached RS, de Toledo BE, Okamoto T, Marcantonio Junior E, Sampaio JE, Orrico SR, Marcantonio RA. Reaction of the human gingival tissue to different suture materials used in periodontal surgery. Braz Dent J 1992; 2: 103-113.

11) DeNardo GA, Brown NO, Trenka-Benthin S, Marretta SM. Comparison of seven different suture materials in the feline oral cavity. J Am Anim Hosp Assoc 1996; 32: 164-172.

12) Selvig KA, Biagiotti GR, Leknes KN, Wikesjo UM. Oral tissue reactions to suture materials. Int J Periodontics Restorative Dent 1998; 18: 474-487.

13) Shaw RJ, Negus TW, Mellor TK. A prospective clinical evaluation of the longevity of resorbable sutures in oral mucosa. Br J Oral Maxillofac Surg 1996; 34: 252-254.

14) Banche G, Roana J, Mandras N, Amasio M, Gallesio C, Allizond V, Angeretti A, Tullio V, Cuffini AM. Microbial adherence on various intraoral suture materials in patients undergoing dental surgery. J Oral Maxillofac Surg 2007; 65: 1503-1507.

15) Von Fraunhofer JA, Storey RJ, Masterson BJ. Tensile properties of suture materials. Biomaterials 1988; 9: 324327.

16) Hertweck SP, von Fraunhofer JA, Masterson BJ. Tensile characteristics of PTFE sutures. Biomaterials 1988; 9: 457459.

17) Yaltirik M, Dedeoglu K, Bilgic B, Koray M, Ersev H, Issever H, Dulger O, Soley S. Comparison of four different suture materials in soft tissues of rats. Oral Dis 2003; 9: 284-286.

18) Nary Filho H, Matsumoto MA, Batista AC, Lopes LC, de Goes FC, Consolaro A. Comparative study of tissue response to polyglecaprone 25, polyglactin 910 and polytetrafluorethylene suture materials in rats. Braz Dent J 2002; 13: 86-91.

19) Setzen G, Williams EF 3rd. Tissue response to suture materials implanted subcutaneously in a rabbit model. Plast Reconstr Surg 1997; 100: 1788-1795.

20) Bajaj MS, Sastry SS, Ghose S, Betharia SM, Pushker N. Evaluation of polytetrafluoroethylene suture for frontalis suspension as compared to polybutylate-coated braided polyester. Clin Experiment Ophthalmol 2004; 32: 415-419.

21) Modak M, Dixit P, Londhe J, Ghaskadbi S, Paul ADT. Indian herbs and herbal drugs used for the treatment of diabetes. $J$ Clin Biochem Nutr 2007; 40: 163-173.

22) Gardiner P, Legedza A, Woods C, Phillips RS, Kemper KJ. Herb use among health care professionals enrolled in an online curriculum on herbs and dietary supplements. J Herb Pharmacother 2006; 6: 51-64.

23) Hanus LO, Rezanka T, Dembitsky VM, Moussaieff A. Myrrh -Commiphora chemistry. Biomed Pap Med Fac Univ Palacky Olomouc Czech Repub 2005; 149: 3-27.

24) Borrelli F, Izzo AA. The plant kingdom as a source of antiulcer remedies. Phytother Res 2000; 14: 581-591.

25) Kimura I, Yoshikawa M, Kobayashi S, Sugihara Y, Suzuki M, Oominami H, Murakami T, Matsuda H, Doiphode VV. New triterpenes, myrrhanol A and myrrhanone A, from guggulgum resins, and their potent anti-inflammatory effect on adjuvant-induced air-pouch granuloma of mice. Bioorg Med Chem Lett 2001; 11: 985-989.

26) Al-Rowais NA. Herbal medicine in the treatment of diabetes mellitus. Saudi Med J 2002; 23: 1327-1331.

27) Tonkal AM, Morsy TA. An update review on Commiphora molmol and related species. J Egypt Soc Parasitol 2008; 38: 763-796.

28) Shonouda ML, Farrag RM, Salama OM. Efficacy of the botanical extract (myrrh), chemical insecticides and their combinations on the cotton leafworm, Spodoptera littoralis boisd (Lepidoptera: Noctuidae). J Environ Sci Health B 2000; 
35: 347-356.

29) Buckley SA, Evershed RP. Organic chemistry of embalming agents in Pharaonic and Graeco-Roman mummies. Nature 2001; 413: 837-841.

30) Al-Mobeeriek A. Effects of myrrh on intra-oral mucosal wounds compared with tetracycline- and chlorhexidinebased mouthwashes. Clin Cosmet Investig Dent 2011; 3: 5358.

31) Nomicos EY. Myrrh: medical marvel or myth of the Magi? Holist Nurs Pract 2007; 21: 308-323.

32) Dolara P, Corte B, Ghelardini C, Pugliese AM, Cerbai E, Menichetti S, Lo Nostro A. Local anaesthetic, antibacterial and antifungal properties of sesquiterpenes from myrrh. Planta Med 2000; 66: 356-358.

33) Al-Harbi MM, Qureshi S, Raza M, Ahmed MM, Giangreco $\mathrm{AB}$, Shah AH. Anticarcinogenic effect of Commiphora molmol on solid tumors induced by Ehrlich carcinoma cells in mice. Chemotherapy 1994; 40: 337-347.

34) Dolara P, Luceri C, Ghelardini C, Monserrat C, Aiolli S, Luceri F, Lodovici M, Menichetti S, Romanelli MN. Analgesic effects of myrrh. Nature 1996; 379: 29.

35) Saeidi M, Azadbakht M, Semnani K, Khandan M. Formulation of herbal toothpaste from chamomile and myrrh, a preliminary clinical evaluation on bleeding gum. J Mazandaran Univ Med Sci 2003; 13: 61-69.

36) Bradley PR. British herbal compendium. Volume 1. A handbook of scientific information on widely used plant drugs. Companion to Volume 1 of the British Herbal Pharmacopoeia. Bournemouth: British Herbal Medicine Association; 1992.

37) Rao RM, Khan ZA, Shah AH. Toxicity studies in mice of Commiphora molmol oleo-gum-resin. J Ethnopharmacol 2001; 76: 151-154.

38) Omer SA, Adam SE. Toxicity of Commiphora myrrha to goats. Vet Hum Toxicol 1999; 41: 299-301.

39) Omer SA, Adam SE, Khalid HE. Effects on rats of Commiphora myrrha extract given by different routes of administration. Vet Hum Toxicol 1999; 41: 193-196.

40) Soderholm KJM, Mukherjee R, Longmate J. Filler leachability of composites stored in distilled water or artificial saliva. J Dent Res 1996; 75: 1692-1699.

41) Levine M, Aguirre A, Hatton MN, Tabak LA. Artificial salivas: present and future. J Dent Res 1987; 66: 693-698.

42) Lemenih M, Teketay D. Frankincense and myrrh resources of Ethiopia: II. Medicinal and industrial uses. SINET: Ethiopian J Sci 2003; 26: 161-172.

43) Sheir Z, Nasr AA, Massoud A, Salama O, Badra GA, ElShennawy H, Hassan N, Hammad SM. A safe, effective, herbal antischistosomal therapy derived from myrrh. Am J Trop Med Hyg 2001; 65: 700-704.

44) Michie CA, Cooper E. Frankincense and myrrh as remedies in children. J R Soc Med 1991; 84: 602-605.

45) Bakhotmah BA, Alzahrani HA. Self-reported use of complementary and alternative medicine (CAM) products in topical treatment of diabetic foot disorders by diabetic patients in Jeddah, Western Saudi Arabia. BMC Res Notes
2010; 3: 254.

46) Al-Faris EA, Al-Rowais N, Mohamed AG, Al-Rukban MO, AlKurdi A, Balla Al-Noor MA, Al-Harby S, Sheikh A. Prevalence and pattern of alternative medicine use: the results of a household survey. Ann Saudi Med 2008; 28: 4-10.

47) El Ashry ES, Rashed N, Salama OM, Saleh A. Components, therapeutic value and uses of myrrh. Pharmazie 2003; 58: 163-168.

48) Leung A, Foster S. Encyclopedia of common natural ingredients used in food, drugs and cosmetics. 2nd ed. New York: John Wiley \& Sons; 1996. pp. 382-383.

49) Hartwell JL. Plants used against cancer: a survey. Lloydia 1967; 30: 379-436.

50) Ageel A, Mossa J, Al-Yahya M, Tariq M, Al-Said M. Plants used in Saudi folk medicine. Experimental report submitted to the King Abdulaziz City for Science and Technology 1987.

51) Von Fraunhofer JA, Storey RS, Stone IK, Masterson BJ. Tensile strength of suture materials. J Biomed Mater Res 1985; 19: 595-600.

52) Herrera D, Roldan S, Santacruz I, Santos S, Masdevall M, Sanz M. Differences in antimicrobial activity of four commercial $0.12 \%$ chlorhexidine mouthrinse formulations: an in vitro contact test and salivary bacterial counts study. J Clin Periodontol 2003; 30: 307-314.

53) Brecx M, Macdonald LL, Legary K, Cheang M, Forgay MG. Long-term effects of $\mathrm{Meridol}^{\circledR}$ and chlorhexidine mouthrinses on plaque, gingivitis, staining, and bacterial vitality. J Dent Res 1993; 72: 1194-1197.

54) Moy RL, Lee A, Zalka A. Commonly used suture materials in skin surgery. Am Fam Physician 1991; 44: 2123-2128.

55) Gerber C, Schneeberger AG, Beck M, Schlegel U. Mechanical strength of repairs of the rotator cuff. J Bone Joint Surg Br 1994; 76: 371-380.

56) Ketchum LD. Suture materials and suture techniques used in tendon repair. Hand Clinics 1985; 1: 43.

57) Muftuoglu MAT, Ozkan E, Saglam A. Effect of human pancreatic juice and bile on the tensile strength of suture materials. Am J Surg 2004; 188: 200-203.

58) McCaul L, Bagg J, Jenkins WMM. Rate of loss of irradiated polyglactin 910 (Vicryl Rapide) from the mouth: a prospective study. Br J Oral Maxillofac Surg 2000; 38: 328-330.

59) Ferguson RE Jr, Schuler K, Thornton BP, Vasconez HC, Rinker B. The effect of saliva and oral intake on the tensile properties of sutures: an experimental study. Ann Plast Surg 2007; 58: 268-272.

60) Vasanthan A, Satheesh K, Hoopes W, Lucaci P, Williams K, Rapley J. Comparing suture strengths for clinical applications: a novel in vitro study. J Periodontol 2009; 80: 618-624.

61) Sladen JG, Maxwell TM. Experience with 130 polytetrafluoroethylene grafts. Am J Surg 1981; 141: 546548.

62) Altman GH, Diaz F, Jakuba C, Calabro T, Horan RL, Chen J, Lu H, Richmond J, Kaplan DL. Silk-based biomaterials. Biomaterials 2003; 24: 401-416. 